\title{
That Map You Love, That Saved Your Life
}

My maps, prints, and photographs are responses arising from an effort to stop and listen to the place. I make direct contact with, and in one Body, the experience of being awake and embracing the event. I make artist-editioned maps, prints, artist books, and broadsides in small numbered editions using a variety of matrices: relief, stone E plate lithography, intaglio, collagraph, silk screen, and letterpress. I make responses directly using both dry and wet drawing materials. My lithographic stones are over 100 years old and still in use. Printing, involving multiple matrices, hand-mixed inks, and fine papers that include blind embossing, chine-colle, and trial and error, is done using the two luddite presses: a Gordon Oldstyle letterpress and a Griffin lithograph E etching-intaglio press.

I stop and listen

I stop and observe

I return back and stop again, and again

STOP, OBSERVE, EXPERIENCE

I count

I measure

I breathe in and I breathe out

AND I sing like Walt and Kabir and Lorca

I experience the place itSelf

this, this drug of song and dance and colour

I touch and feel and enJOY

and get wet

and get dirty

and get cold and hot and hurt and healed sun-cloud-water exposed

\section{Did I say this?}

And when the place speaks

And I hear the Voice

\section{MAKE}

to Make a mark

to Respond

a response arising from the place itSelf

I-Thou, the Other

Listening

I can no longer make maps

These are given to me,

Gifts that saved my life 


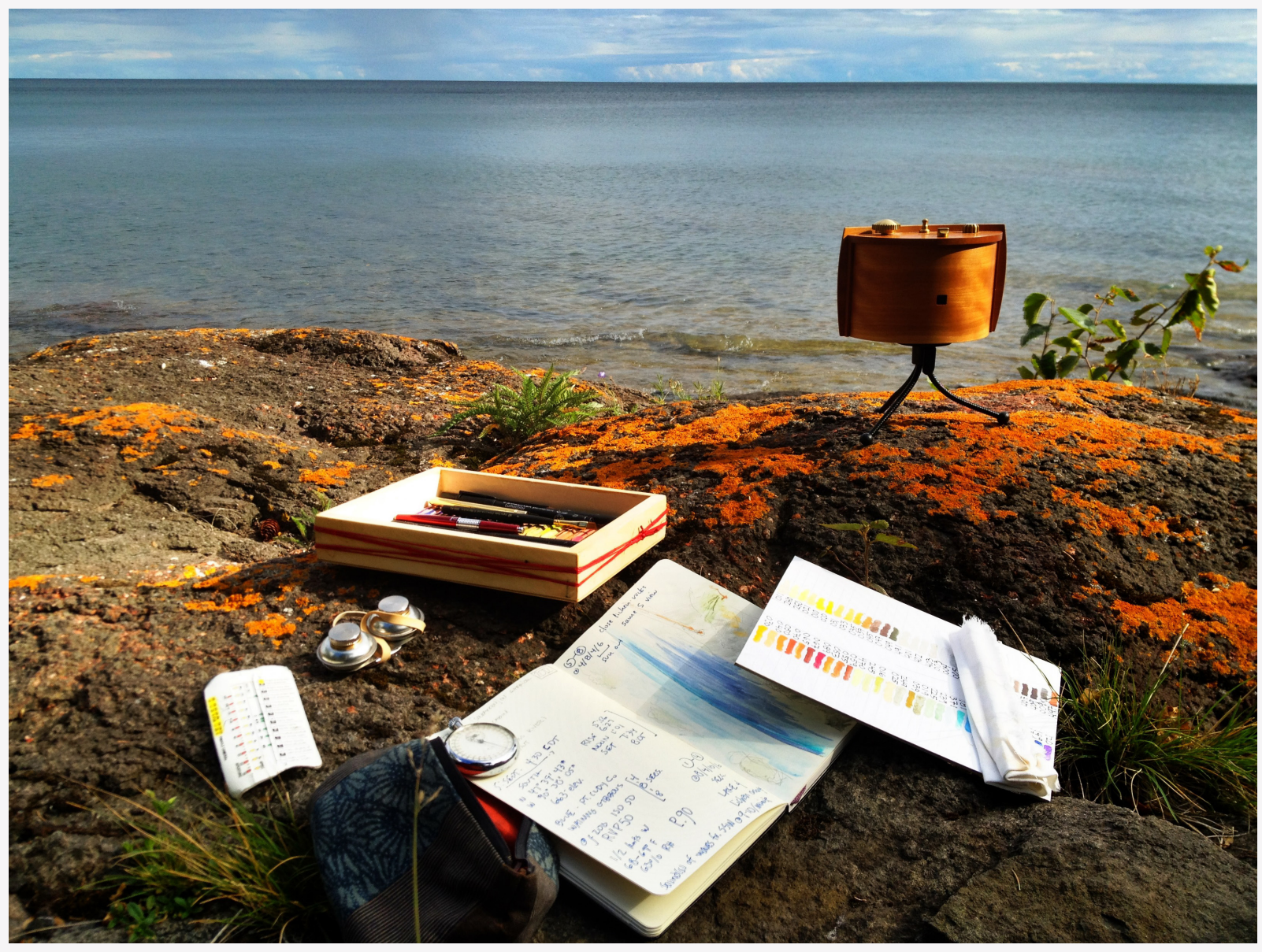


After the Indian Wars

the new King placed a grid like a blanket heavy and suffocating EVERYwhere a permanence of his pleasure and power

AND did what he wanted

Gave the land to those in his favor a medal with his image to those he defeated

And thus began the great extractions the steel ribbons the cutting and fencing and the endless concrete the draining \& covering of the swamps the terrible stagnation of the dams

And the poisoning of $\mathrm{ki}-\mathrm{o}-\mathrm{te}$ I-IT. I-IT. I-IT.

ME ME ME they shouted MINE. I WANT. MINE.

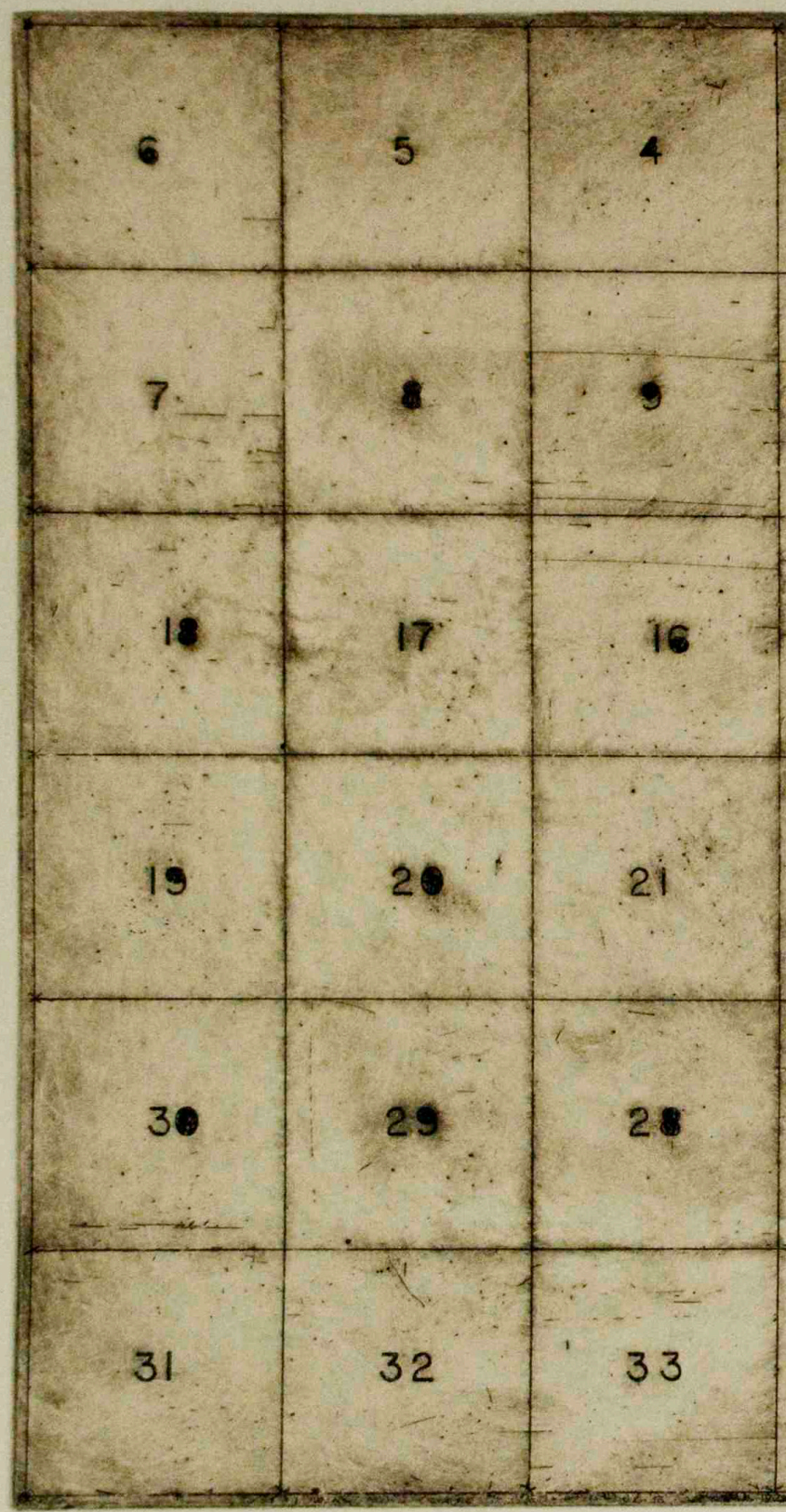

Mapping the World, Intaglio 25 by 38 in. on Sakamoto Aiko, 2009. 
Muddy flooding of the Nile

Rising and falling of the Ganges

the great Tigris-Euphrates, rich valley of mudwater moving life-stuff

Missouri-Ohio-Mississippi, Columbia-Kootenay, Amazon Basin of life

Muddy waters rising and falling

Bearing Witness

the dark walls of Chauvet Cave in the valley of the Ardèche

paintings, engravings and drawings bearing witness

hand prints; I too was here bearing witness with you

And the event at BodhGaya on the Phalgu-Ganges

the Earth bearing witness, mud-waters rising up

his right hand touching the earth,

the waters rising and bearing witness

And Mara disappeared. 


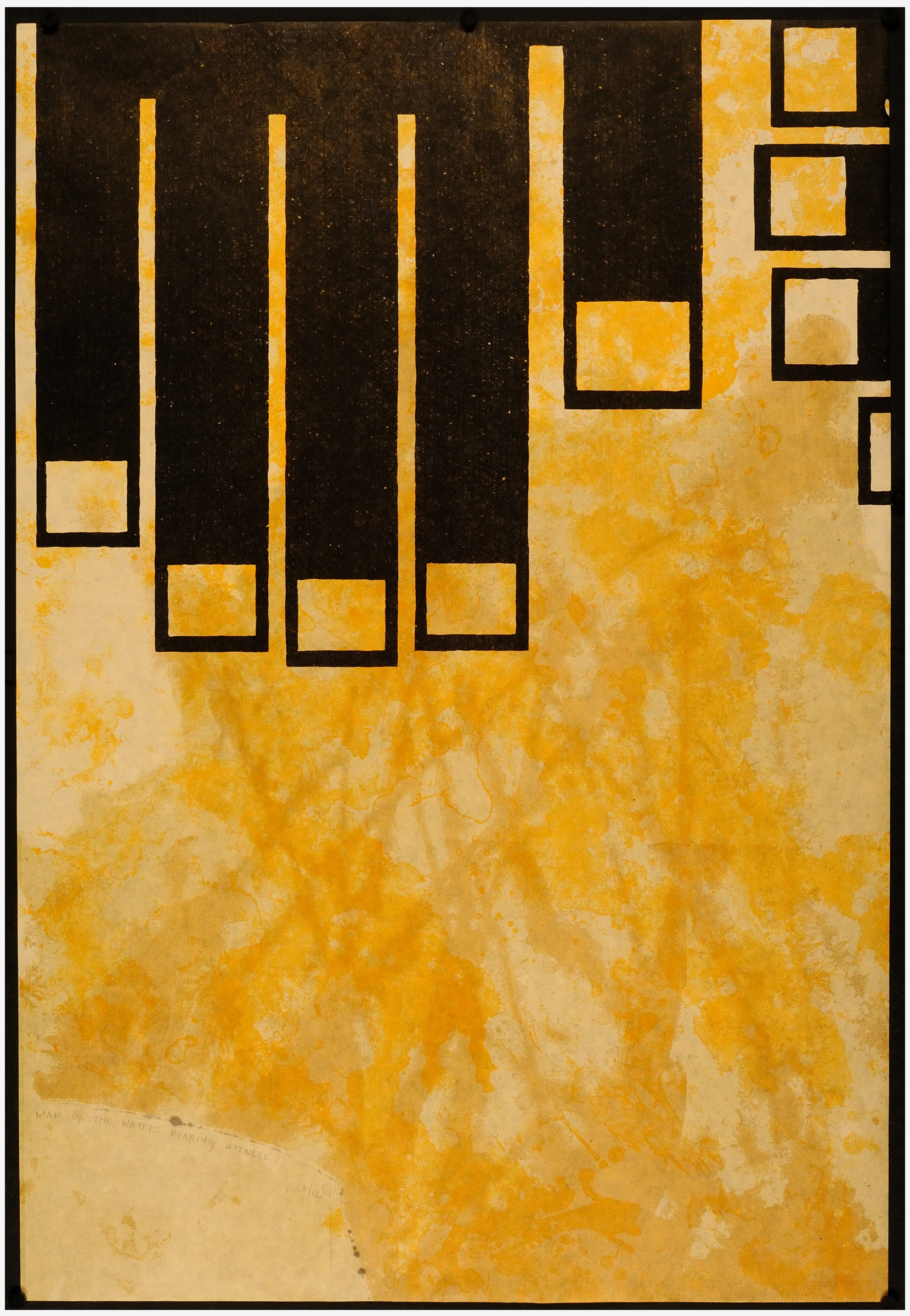




\author{
Stopped here \\ the Place called Three Forks of the Missouri \\ witness to a coming together \\ in winter, in spring, in summer \\ Watersheds polyphonic, water in song \& in dance \\ An assembling and mixing and transporting of \\ My DNA. Your DNA. The DNA. \\ As in a flood all jumbled together. Coming Together. \\ Did we come together as these rivers \\ without effort \\ joining without dispute or judgment \\ How lucky I am \\ making a mark on a cave wall \\ Marks that saved my life \\ Marks \\ to make things that \\ Disrupt and Disturb and Awaken me \\ In spring and in summer and in winter and autumn.
}




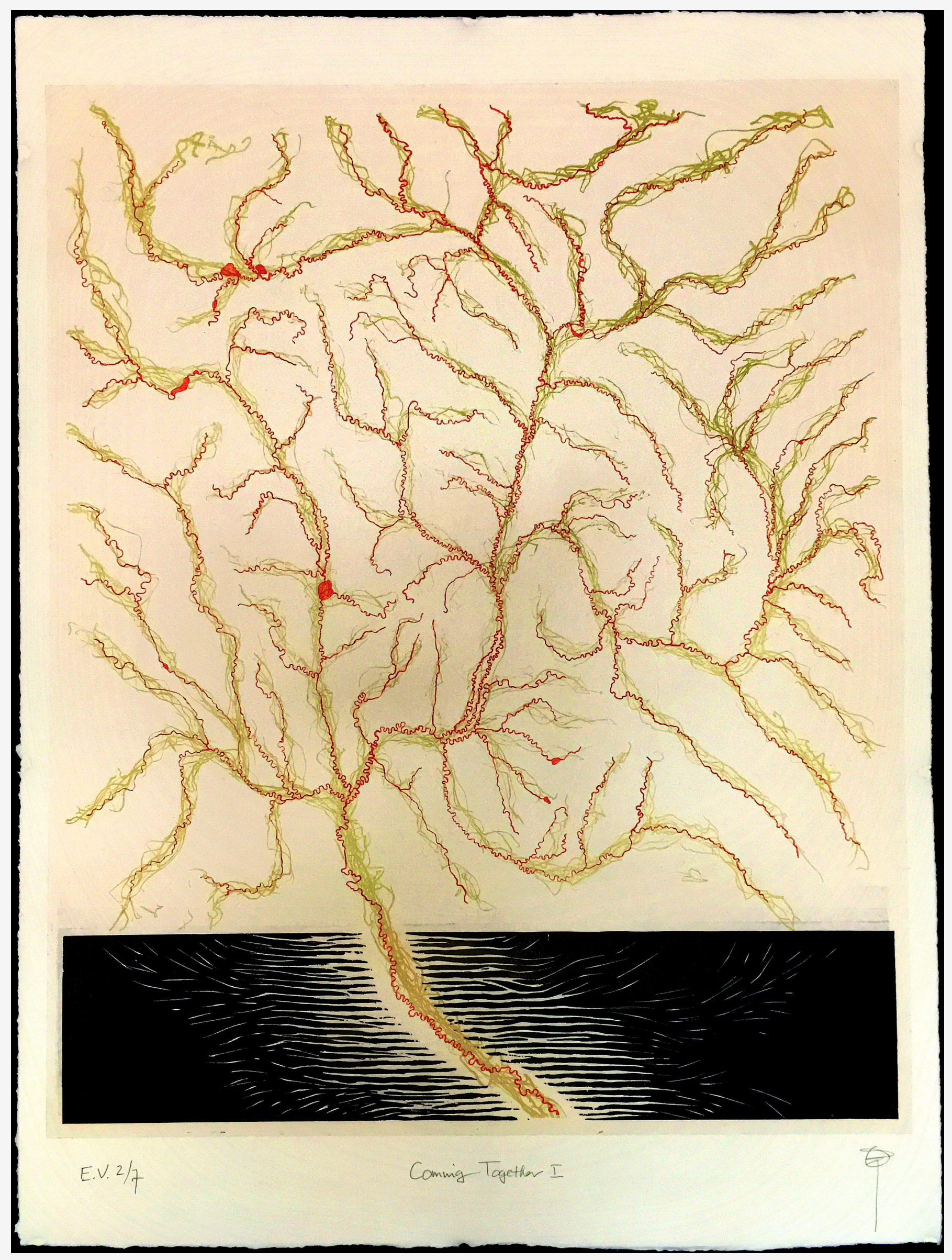


How to cross east to the buffalo people

How to cross west to the salmon people

This is all you need to know

the way across. Leave all the rest to the crossing itself.

To cross the Shining Mountains, Crown of the Continent ...

Crowsnest, Tent Mountain, Ptolemy, North Kootenay, Middle Kootenay, Sage and Kishinenai, Akamina, Boulder, Brown, Jefferson and Kootenai

There is Fifty Mountain, Stoney Indian, Gable at Chief Mountain on the Front, and Ahern, Red Gap, the Tunnel called Ptarmigan and Swiftcurrent

And Logan, Piegan and Siyeh, Hidden Lake, Comeau, Lincoln, Gunsight,

Red Eagle, Cut Bank, Surprise, Triple Divide by the Peak, Pitamakan

Then Dawson, Two Medicine, deSanto, Firebrand, Marais,

Muskrat, Badger, Gateway, Teton

Crossings without end. Mountains and Rivers without end.

The WAY across. 


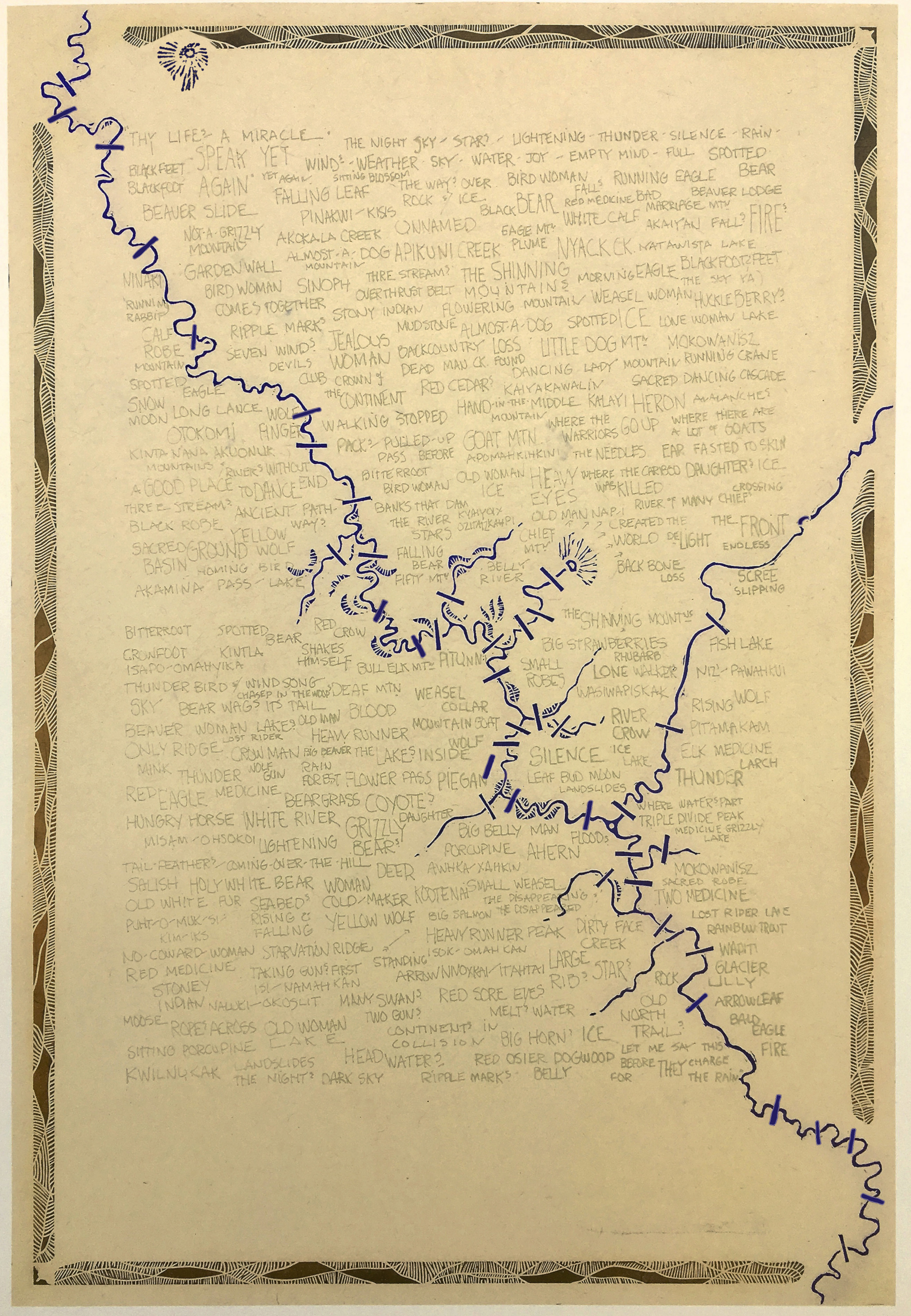



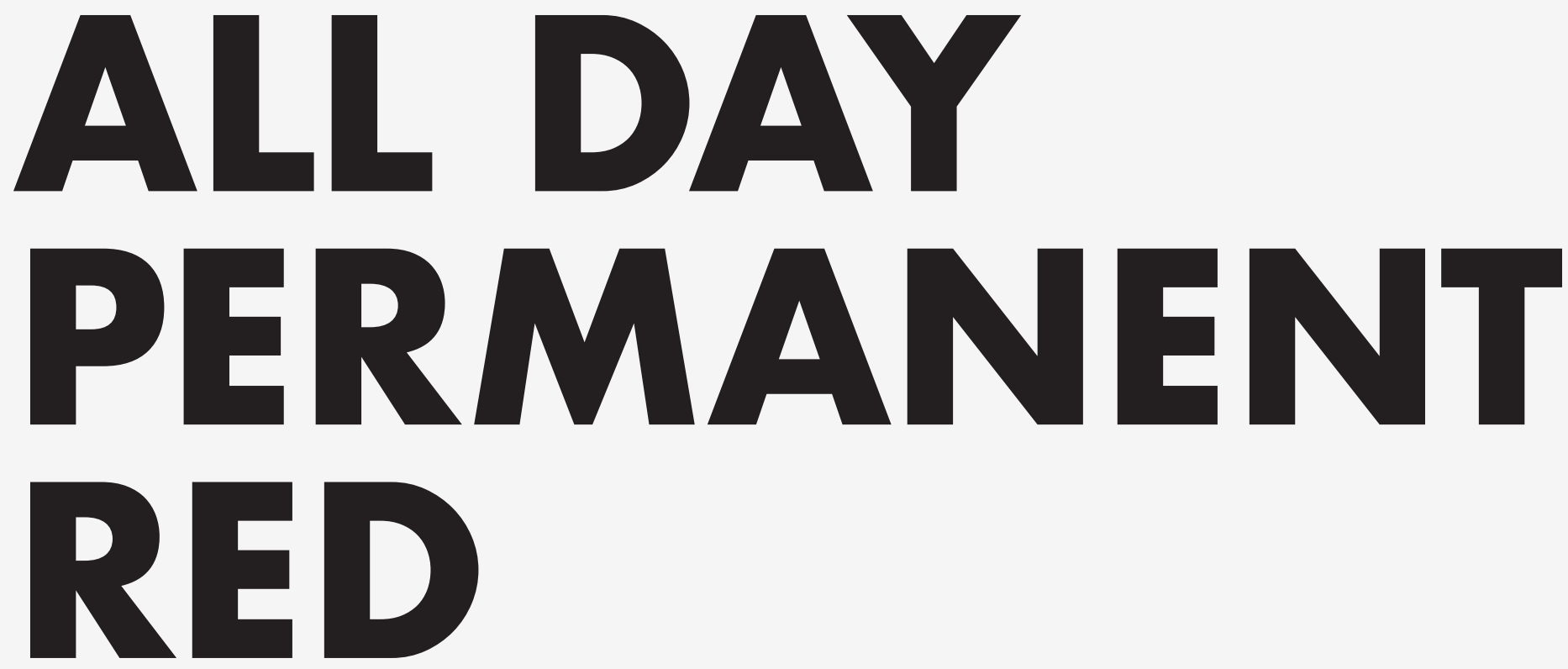

All Day Permanent Red: The First Battle Scenes of Homer's lliad, rewritten by Christopher Logue, 2003. 


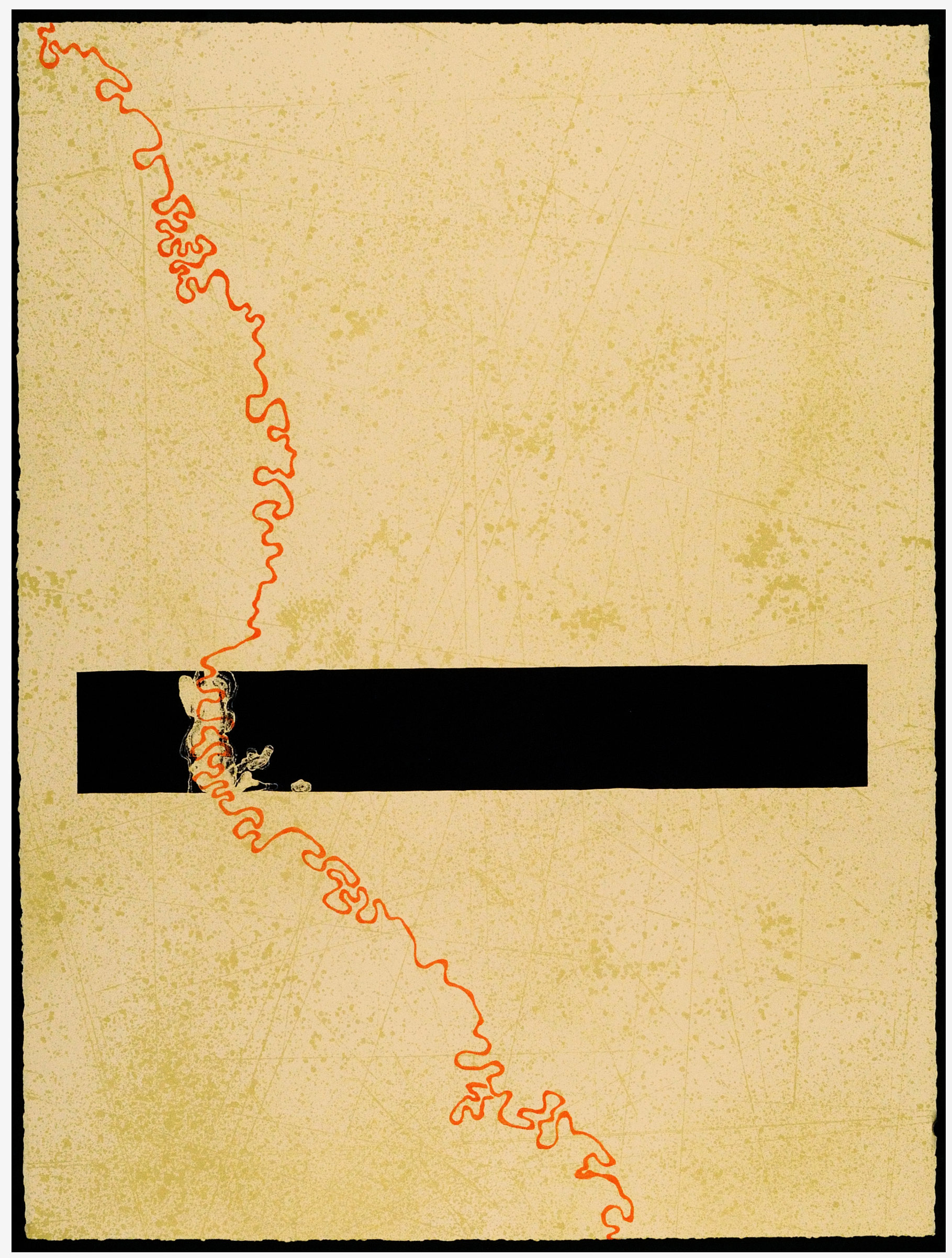


At night the river is an inky blackness, the bottom of which I cannot locate, more than a shadow, an eclipse of sorts, a doorway that invites me in. I stand back and look out now, and the song of the night is shimmering awake. Above, on the surface, gold reminds me of something. I cannot distinguish between the night and the shimmering gold. At this moment the gold has no price and cannot be sold.

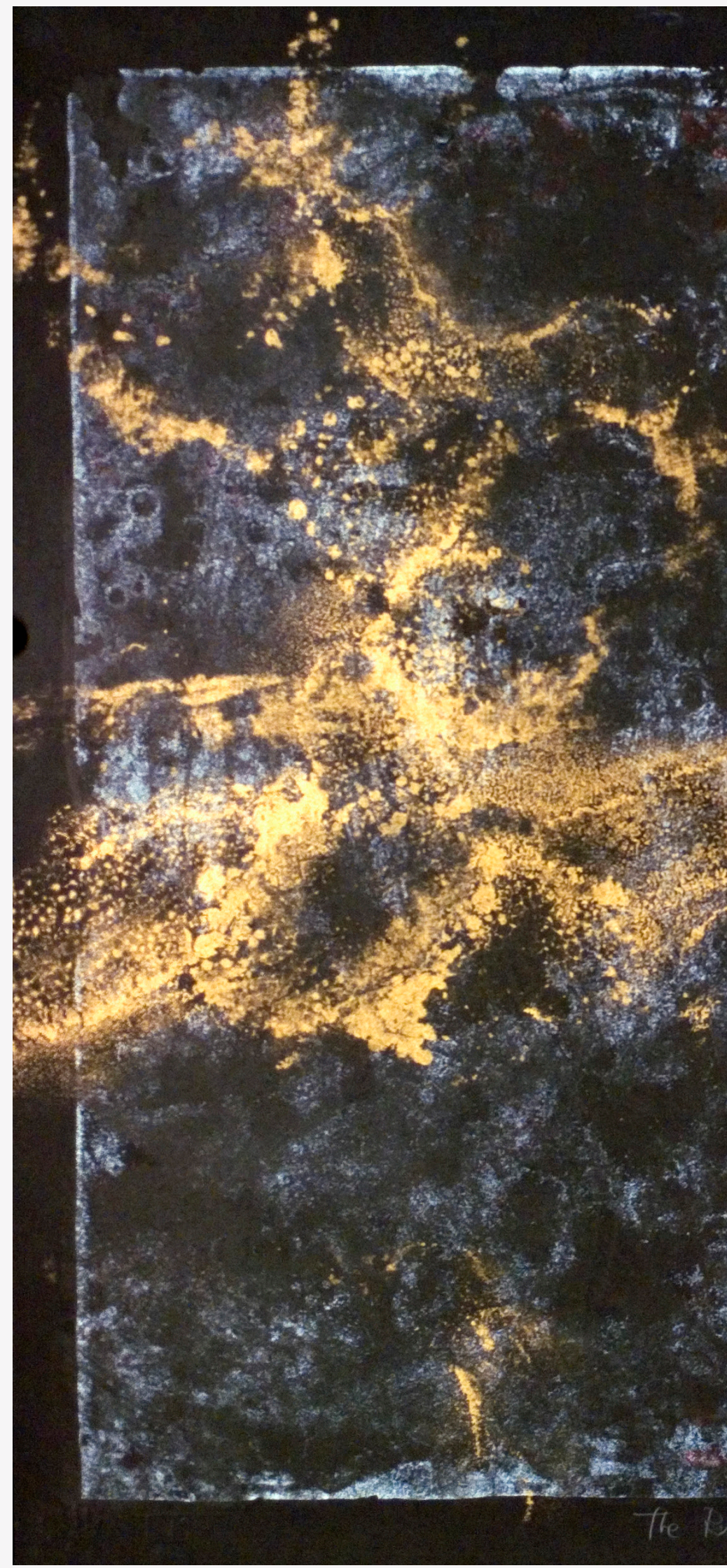

The River Awakens at Night (Missouri River at the junction of the Arrow, Montana), 22 by 30 in. Stone lithograph on Somerset Velvet Black, 2004. 
And the heron, in its constant dance,

its thinking, along the Vermilion River links as the poem, the map-poem, everything together, everything interwoven, interconnected, changing, song and dance.

Every morning, in the wild rice shallows

I look for the heron and wonder what it has dreamed.

In what sense can a map, the domesticated map, ever know the dreams of the heron in flight, in stillness.

The river is the place where your voice came into song.

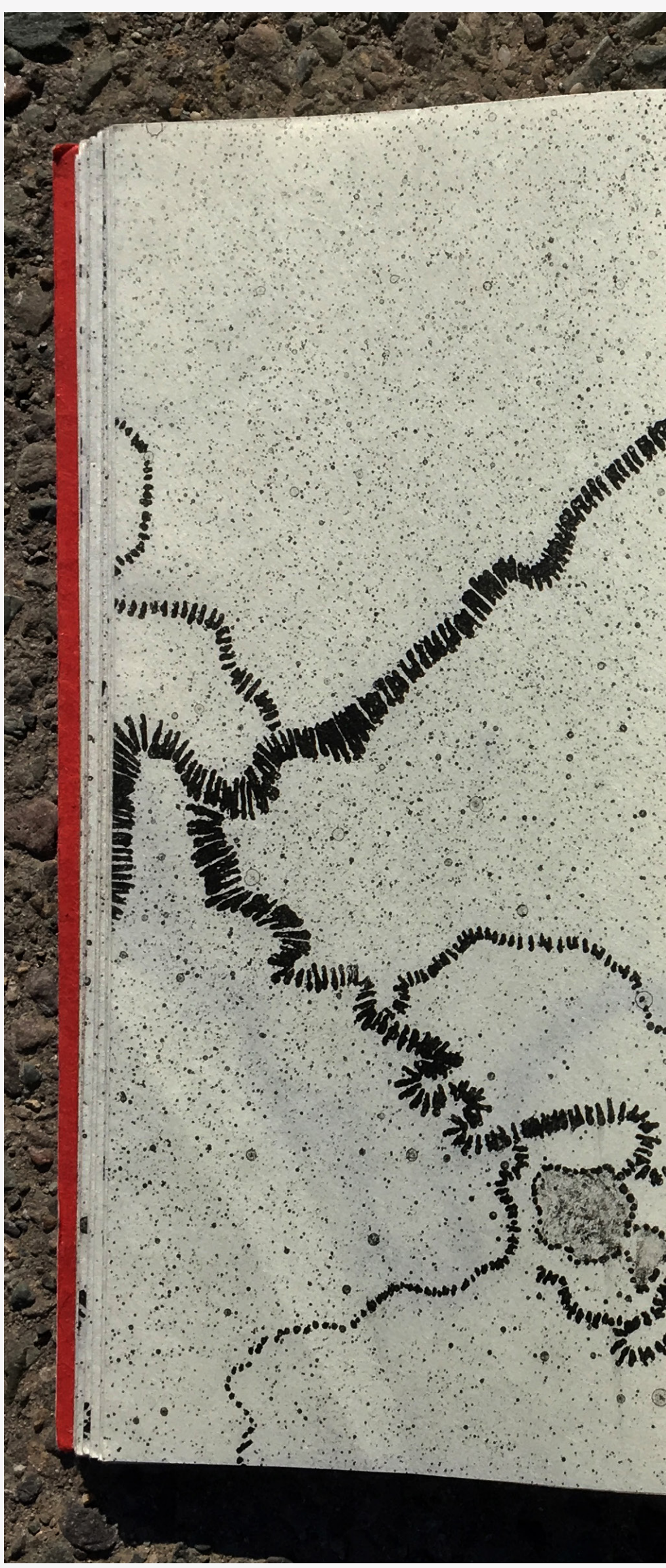

Flight Path of the Heron (Vermilion River \& tributaries, Vermilion Lake to Crane Lake, Minnesota), 11 by 8 in. hand bound. Artist Book \& Lithograph, 2007. 


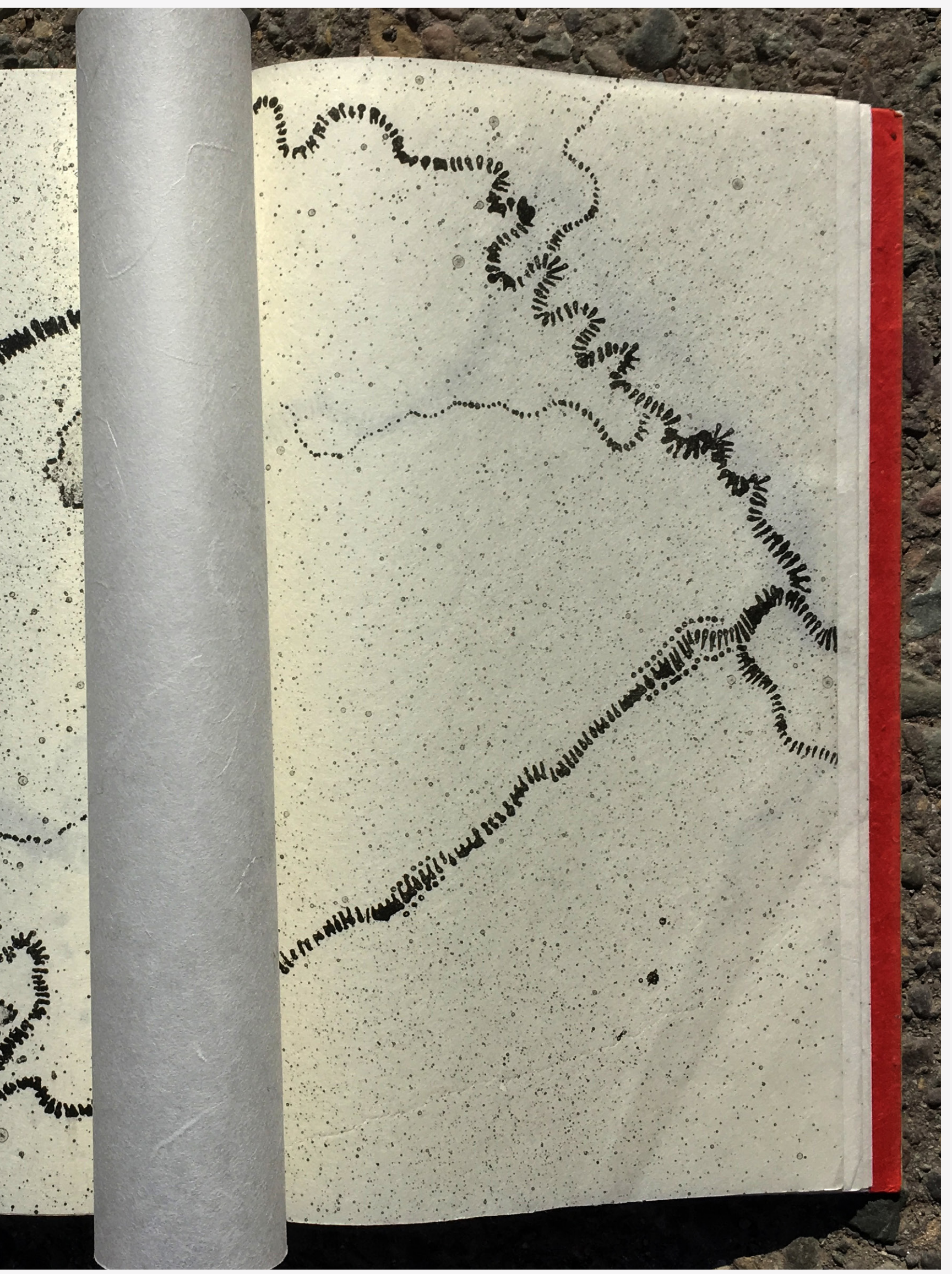

Flight Path of the Heron (Vermilion River \& tributaries, Vermilion Lake to Crane Lake, Minnesota), 11 by 8 in. hand bound. Artist Book \& Lithograph, 2007 (continued). 
Weightless

The tide, its waters in and out from the sea

The currents, swirling in the bay

The wind, the sun, the waves, the spray

I am swimming within all these now

and between the sky and the salty water.

The pilot boat is nowhere

then suddenly everywhere and nowhere to be seen

rising and falling in the waves

we are in the water, we are so very small

swimming the Golden Gate under power of arms, lungs, legs

being lifted by this, an immense Body

being lowered now, into this Body.

Stroke, Two, Three . . . breathe right, sight for the landing

Stroke, Two, Three . . . breathe left, sight for the pilot suddenly beside me, their eyes looking high above I press against the side of the boat

\& push myself away, turn and look

falls the shadow.

I am swimming in the space between light \& shadow

I am swimming in the moving waters; ahwō

All the while I am being carried

everything unstoppable

everything dancing

everything moving, moving out to sea.

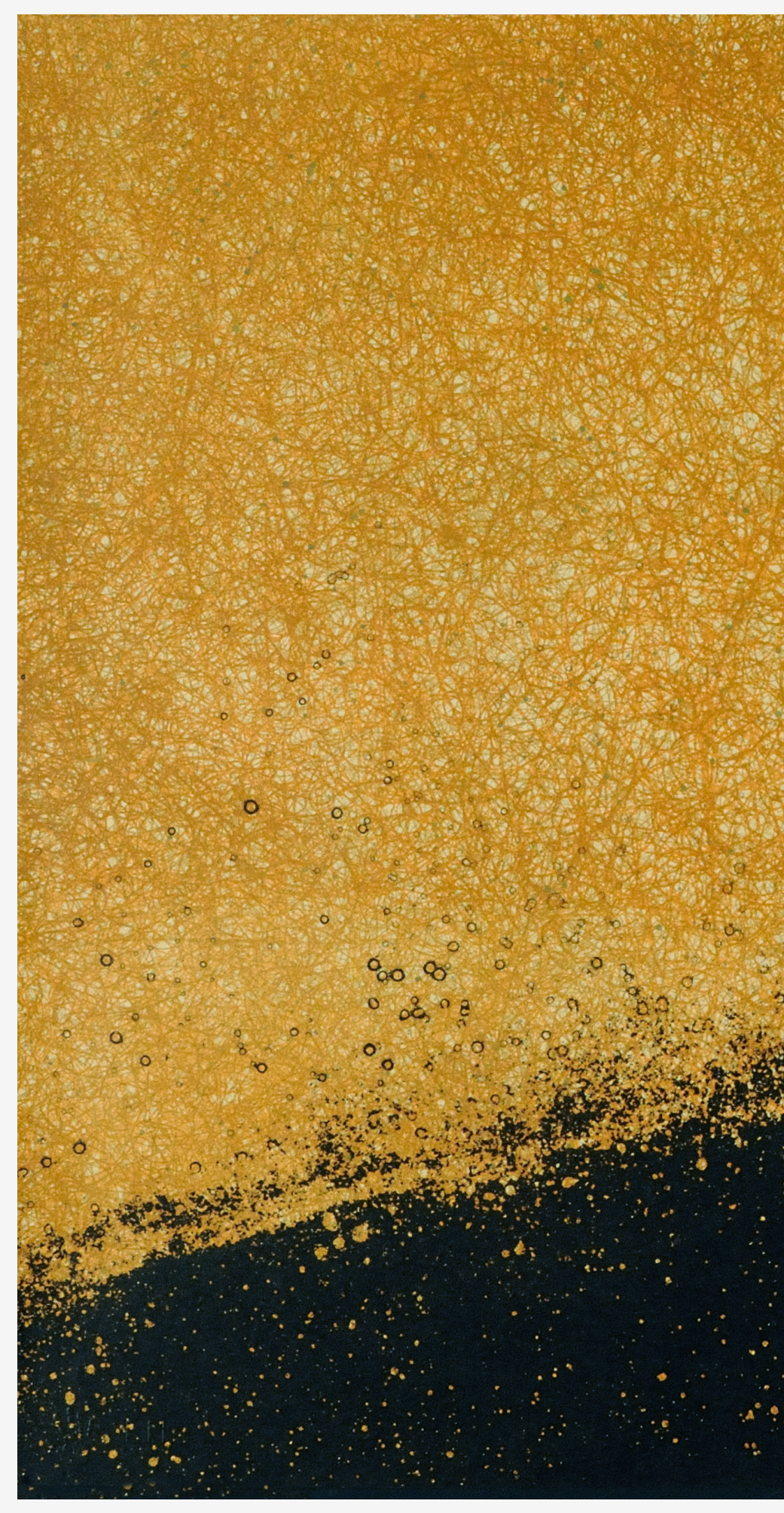

Falls the Shadow (The Golden Gate \& the shadow of the Golden Gate bridge, California), 25 by 38 in. Stone lithograph on Sakamoto, 2008. 


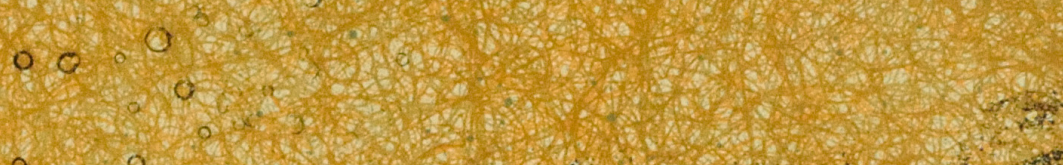
5.

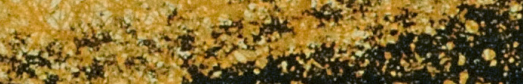

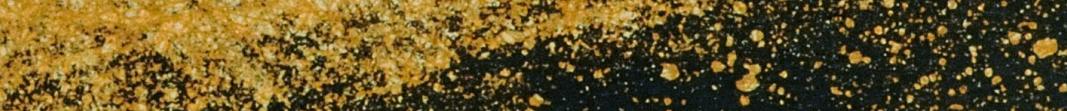
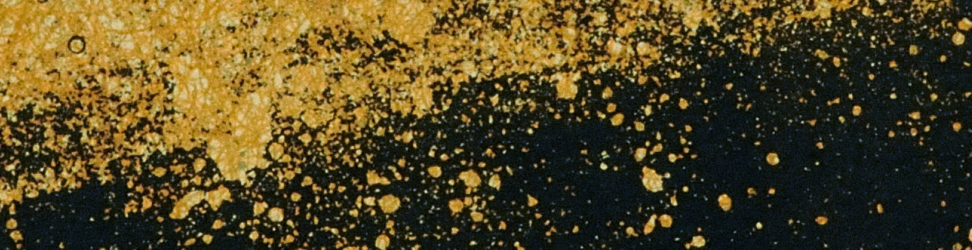

$6:$
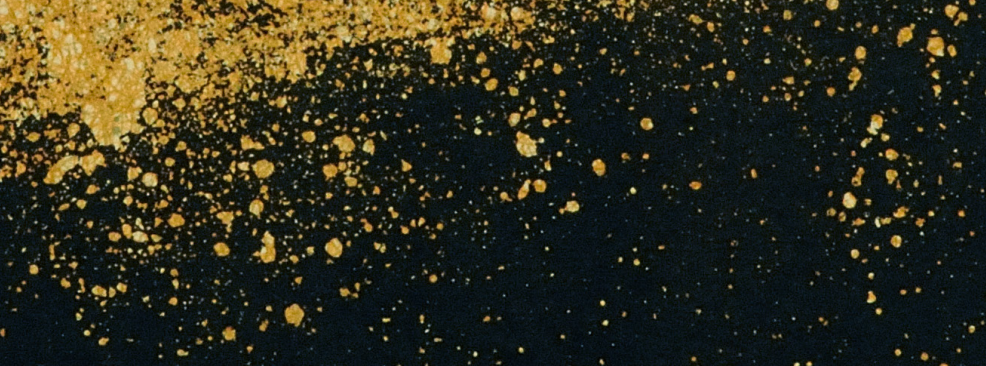

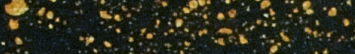
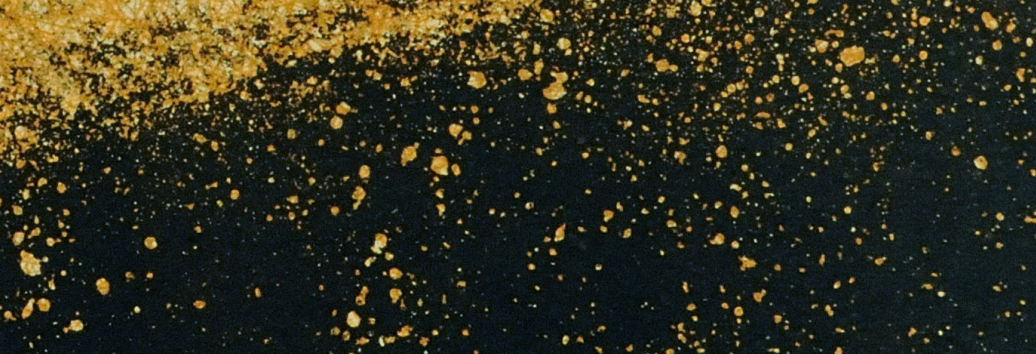

$\because$
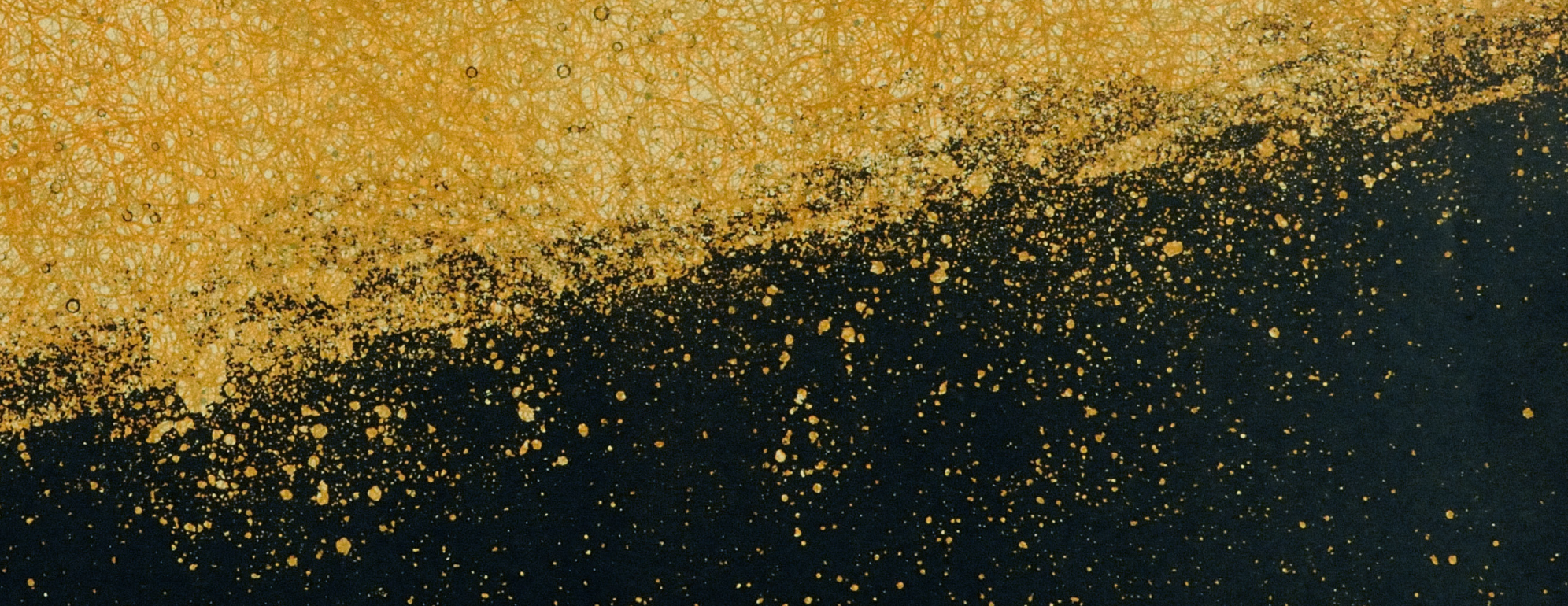

$\therefore$
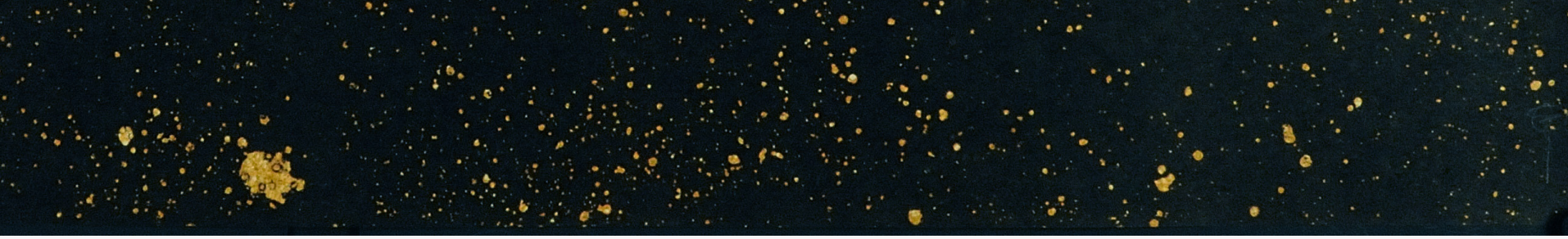

Falls the Shadow (The Golden Gate \& the shadow of the Golden Gate bridge, California), 25 by 38 in. Stone lithograph on Sakamoto, 2008 (continued) 